THE IDENTITY OF THE WHEAT MIDGE IN ONTARIO.

BY W. A. ROSS, DOMINION ENTOMOLOGICAL LABORATORY, VINELAND STA., ONT.

In connection with the re-appearance in Ontario of the wheat midge-or "red weevil" in fairly large numbers in 1917 and in lesser numbers this year, it is worth while recording that our species is Thecodiplosis mosellana Gehin, and not as we thought, Cecidomyia, or Diplosis, tritici Kirby. This summer I reared a considerable number of adult midges from larve collected in 1917 in

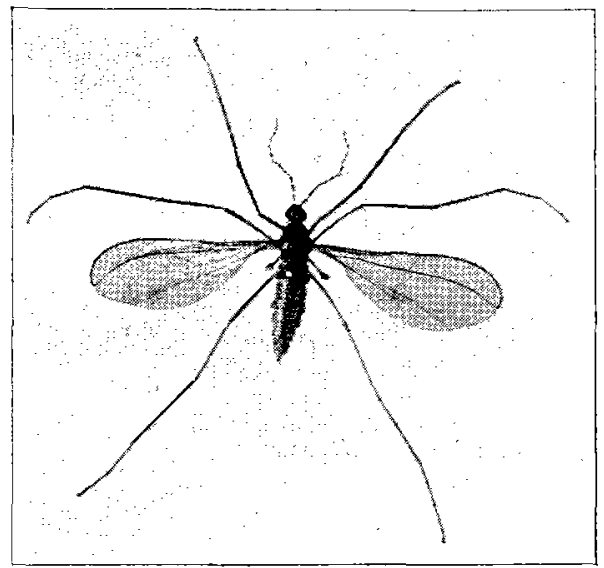

Fig. 1.-Wheat Midge (Thecodiplosis mosellana Gehin.), much enlarged.

Welland and Lincoln Counties and submitted them to Dr. E. P. Felt, who, after making a careful examination, sent me the following report: "I have decided that the species is with very little question Thecodiplosis mosellana Gehin. I

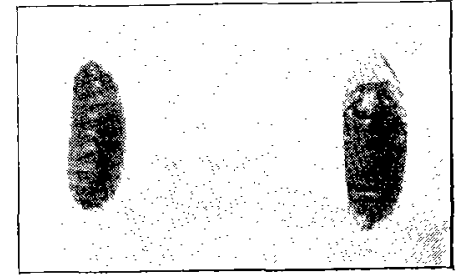

Fig. 2.-Maggots of Wheat Midge, much enlarged. The larva on the right is within its larval case.

find on looking up our records that we reared the same insect in 1912 from wheat heads collected at Batavia, N.Y., and the probabilities are, so far as this country is concerned, that this is the destructive wheat midge. . . . I am well satisfied that this is not the Cecidomyia, or Diplosis, tritici Kirby unless the characterizations and illustrations of this insect are erroneous, something we are hardly warranted in assuming."

\title{
CATOCALA ULALUME STRECK. VS. CATOCALA CAROLINA HOLLAND.
}

BY G. H. FRENCH, CARBONDALE, ILL.

In September, 1877, Herman Strecker described Catocala ulalume in his serial, "Lepidoptera Rhopaloceres et Heteroceres," page 132. In the April number of the Bulletin of the Brooklyn Entomological Society for 1880, page 97, Mr. Strecker describes Catocala dejecta. I have taken both of these in this (Jackson) County, Ill., and if my memory serves me correctly a specimen of ulalume was submitted to Mr. Strecker for identification.

In his book, "The Moth Book," Dr. W. J. Holland figures Catocala carolina as a new sub-species- the date of copyright of both being 1903.

This season I have taken a number of Catocala ulalume, some of them of the size of Dr. Holland's figure, while others are larger. Why is not Dr. Holland's C. carolina Mr. Strecker's C. ulalume? The markings are the same and they are constant. I would not class it as a form of $L$. dejecta without breeding. I tried to get eggs this season to breed it but failed. I always find C. ulalume on hickory trees, sometimes several on the same tree, having much the habit of $C$. flebilis. 